\title{
Securing the market: Water security and the internal contradictions of Chile's Water Code
}

\section{$\underline{\text { Abstract }}$}

Chile has operated a system of private tradable water rights since 1981. In theory, this framework contributes to water security by instituting private property rights to water to enable permanent access, and by using market transactions to facilitate the reallocation of scarce water to ensure optimal distribution. Yet, since 2010, the country has faced critical water scarcity in several regions, arising from a combination of overexploitation and dry weather. The aim of this paper is to analyse the relationship between water markets and water security in Chile. It has two objectives: to examine how the water policy framework has shaped responses to acute water scarcity, based on a case study of the La Ligua river basin during the 2014-15 drought, and to explore how water-society relations have influenced the nature and implications of these responses. The analysis employs a relational approach to water security that attends to the configuration of hydrosocial relations, as opposed to the supply of water. I make three related arguments. First, the framework fostered supply-led responses to drought that were counterproductive to water security. Second, these responses can be attributed to the privatised and individualised hydrosocial relations under the market system, which now present an internal contradiction by threatening to undermine it. Third, supply-led responses were not merely pragmatic solutions to water shortages, but a means to neutralise this internal contradiction so as to stave off the potential destabilisation of the water policy framework. 


\section{$\underline{\text { Keywords }}$}

Water markets, drought, export agriculture, capital accumulation, hydrosocial cycle, political ecology.

\section{Introduction}

Chile has adopted the principles of water privatisation and markets to the greatest extent internationally. The 1981 Water Code introduced a system of tradable private water rights with minimal government regulation, that sought to use the principles of private property and market transactions to enable the efficient (re)allocation of water. This framework was moderately reformed in 2005 (Budds, 2013), and further reforms were proposed in 2015 . $^{1}$ Several authors have analysed the empirical outcomes of the Water Code across regions, sectors and users in Chile (e.g. Bauer, 1997, 1998b; Budds, 2004, 2008, 2009b, 2010; Prieto, 2015, 2016; Romano and Leporati, 2002). Their work has shed light on the practical functioning of the framework, evidencing its effects on water allocation, livelihoods, cultural identity, ecosystems, and

\footnotetext{
${ }^{11}$ These were passed by the Chamber of Deputies in November 2016. At the time of writing (June 2018), they were under debate in the Senate.
} 
water governance, and challenging previous claims of positive outcomes (Bauer, 2015). ${ }^{2}$

This prior work has examined the functioning of the market-led water policy framework in the context of prevailing water scarcity in Chile. Findings have suggested that provision for trading water rights does not manage demand, even in arid and semi-arid regions, because water users often look to new sources (e.g. aquifers, reservoirs) rather than the market, because users are generally reluctant to purchase water rights, and because the supply of water rights does not always meet demand (Budds, 2004, 2008, 2009a). However, what has been far less explored is how the framework functions in situations of unusual and/or unexpected acute scarcity, which have become more prevalent in Chile since 2010, even in temperate regions of the country (although see Guiloff (2013)). Water scarcity is associated with the effects of regional (El Niño Southern Oscillation), and potentially global, climatic variations, but is also connected with high demand among natural resource based export industries (mining, agriculture, timber) (DGOP, 2017). Therefore, it is both necessary and timely to extend existing assessments of how the provisions of the Water Code relate to prevailing water scarcity, and to examine how they respond to situations of unexpected acute scarcity, as well as to contemplate the broader dynamics that underlie these responses.

Water security is an increasingly influential concept in policy and scholarship, to promote the long-term provision of water for human, economic and

\footnotetext{
${ }^{2}$ Such claims continue to be repeated, yet without supporting evidence (e.g. Donoso et al., 2012).
} 
environmental needs, and the policy and governance measures needed to achieve this (e.g. Grey and Sadoff, 2007). As Jepson et al. (2017) note, most literature conceptualises water security in terms of securing the supply of water, thereby neglecting the water-society relations that may underpin water insecurity and that thus may merit transformation to promote water security (see also Budds and Loftus, 2014; Loftus, 2015). These authors, therefore, argue that water security should not be regarded as a state characterised by the presence of adequate water, but rather as "a relationship that describes how individuals, households, and communities navigate and transform hydrosocial relations to access the water that they need and in ways that support the sustained development of human capabilities and wellbeing in their full breadth and scope" (Jepson et al., 2017: 50, emphasis in original).

In Chile, the term 'water security' (seguridad hídrica) is increasingly deployed to denote the imperative to protect the availability of water resources for human and economic needs, especially vis-à-vis climate change. ${ }^{3}$ While some reports place emphasis on the management of water itself, through water storage infrastructure, integrated water and catchment management, and water supply and demand (Donoso et al., 2012; MOP, 2017a), others stress the stress the human and development dimensions of water security, including prioritisation of water for basic needs and domestic livelihoods, conservation of water resources and aquatic ecosystems, sustainable and coordinated water use among economic sectors, and protection against

\footnotetext{
${ }^{3}$ Climate change is prominent in both policy arenas and the public imagination in Chile, related to glacier melt, reduced precipitation, and increased droughts.
} 
water-related hazards (DGOP, 2017; Peña, 2016). While not necessarily denoted by the term 'water security' as such, security is also associated with the permanent and exclusive tenure afforded by private water rights. ${ }^{4}$ The security of private water rights is contested by previous work, on the basis that water rights are regulated by private law, which not all users are able to access in case of infractions (Budds, 2004), private water rights are easier to alienate than state-granted concessions, as other users can simply use purchasing power to acquire them (Budds, 2009b), and, increasingly, the water represented by a right may be temporarily or permanently exhausted in practice (Budds, 2009a).

My analysis will add to existing scholarship in two principal ways. First, it will assess the functioning of the water market framework under conditions of unusual and/or unexpected acute scarcity, thereby adding to existing analyses that have examined prevailing semi-arid and arid environments in Chile. Second, it will contribute to critical geographical literature that interrogates the concept of water security and its mobilisation in practice. By looking beyond how water is supplied through responses to drought, and instead to how hydrosocial relations configure, and are configured by, such responses, the study aims to shed light on the rationale, motives and prospects of common water security interventions. The analysis draws on qualitative fieldwork conducted in Santiago, Quillota, and La Ligua, Chile, in May and June 2015, comprising semi-structured interviews with key informants from the public sector (including political representatives and

\footnotetext{
${ }^{4}$ This enables water rights to be used as collateral to guarantee credit, and in theory incentivises user investment in water infrastructure.
} 
regional and local officials from relevant agencies) and rural communities (primarily farmers, community leaders, and rural water supply managers), a review of relevant documentation on drought measures, and field observations throughout the La Ligua river basin during this period.

Following this introduction, in Section 2 I set out a conceptual framework of water security grounded in hydrosocial relations to approach the relationship between private tradable water rights and water scarcity. Section 3 then briefly describes the key features of Chile's Water Code, highlighting recent criticisms that are increasingly challenging the framework. In section 4 , I turn to the case of La Ligua, to describe the causes and effects of increased water scarcity since 2009 , and examine responses by government agencies and water users to the 2014-15 drought. Section 5 analyses how far and in what ways these conditions were related to the privatised and marketised water policy framework, as well as the extent to which its key features have been mobilised, and effective, in addressing them. Section 6 concludes with my contention that the Water Code not only exacerbated water scarcity, but also constrained responses to it, by fostering individualistic behaviour and encouraging supply-led solutions. I argue that these dynamics present an internal contradiction to the framework by threatening to undermine it, and I suggest that supply-led responses serve not only to alleviate shortages, but also to neutralise this internal contradiction in the face of growing challenges to the Water Code.

\section{Water markets and water security: Securing what?}


In theory, Chile's system of private tradable water rights is related to water 'security' in two key ways: first, by instituting private property rights to water to guarantee permanent access and foster user investment in infrastructure, and, second, by employing market principles to enable the reallocation of scarce water for optimal distribution (Bauer, 1998a; Muchnik et al., 1997). These propositions reflect the logic of free market economics that private ownership and market transactions will increase the effectiveness and efficiency of water management, thereby contributing to water security, broadly defined (Loftus and Budds, 2016). Indeed, Grey and Sadoff (2007) incorporate this rationale into their approach to water security, framed as the need to protect the availability of water for human and economic needs in the context of human and natural processes of change. Similarly, other authors advocate using economic principles and involving the private sector in water security initiatives (Pahl-Wostl et al., 2013; World Economic Forum, 2011).

However, critical work on water privatisation and marketisation has contested these propositions. Several authors have critiqued the effectiveness of the private sector, arguing that private property rights and commercial principles do not necessarily lead to investment or efficiency (Bakker, 2002, 2003, 2010; Budds and McGranahan, 2003; Spronk, 2007), and that they serve the interests of capital accumulation over human needs (Schulpen and Gibbon, 2002; Swyngedouw, 2005). Others have questioned the efficacy of private and market led initiatives in addressing water scarcity - relating to either water services or water resources, - identifying scarcity as socially constructed and/or socially produced, rather than pre-existing and/or natural (Bakker, 2000; Kaika, 2003; Swyngedouw, 1995). As Bakker (2002) insightfully notes, scarcity is 
required in order for markets to work, and if it does not exist, it must be manufactured to produce this outcome (e.g. via exclusivity rights). What these critiques highlight above all is the need to understand water supply as partly produced through social processes as opposed to the outcome of material conditions alone.

Subsequent work thus moved beyond examining the effects of privatisation and marketisation, and repositioned these as part of a broader process of the ‘neoliberalisation' of water, whereby resource reregulation (e.g. commodification, enclosure, valuation) reconfigured water-society relations in distinct ways (Bakker, 2003, 2010; Loftus and Budds, 2016). Such analyses also served to highlight that water's material properties and cultural meanings rendered it physically and symbolically resistant to market-led approaches (Bakker, 2003; Perreault, 2006), and that water technologies were not inert but played an agential role in water-society relations (Birkenholtz, 2013; Loftus, 2006).

Swyngedouw's (1999) reconceptualisation of water as the manifestation of a process, rather than a pre-existing material substance, extended analyses beyond patterns of allocation and access to inspire a more explicit focus on how social relations can be recast through water. This served to show how control over water has served wider political agendas. For instance, Swyngedouw (1999) argued that the connection of Spain's river basins was designed to foster a new national unity that facilitated the country's subjugation to authoritarian rule in the 1930s, while Vandewalle and Jepson (2015) demonstrated that state interventions to promote household drinking water treatment in low-income communities in Texas reinforced private and individual responsibility over water as a means of 
diminishing state responsibility for service provision. Other authors examined how reregulation does not merely reshape the social relations of control over, and access to, water, but deeper-rooted social subjectivities and identities. For example, Linton (2010) described how the provision of drinking water through public water fountains and bottled water vending in Canadian university campuses fostered the identities of citizen versus consumer, respectively, while O'Reilly (2006) demonstrated how the installation of household water connections in poor rural households in India transformed women's identity from 'traditional' to 'modern'.

In line with this thinking, Loftus (2015) and Jepson et al. (2017) move away from material water as the focus of water security, and instead towards watersociety relations. Jepson et al. (2017) reconceptualise water security from a state that describes the supply of water under specific conditions (quality, quantity, continuity, affordability) to a relationship between people and water, the nature of which configures access and autonomy. This approach opens up questions that go beyond conventional analyses of how 'water' - typically regarded as material, universal and inert - can be secured; and instead contemplate what water is being secured - to acknowledge different types, states or identities of water, and, moreover, what is being secured through water security - water itself, or other objectives? (see Budds et al., 2014; Linton and Budds, 2014).

Approaching water security in a more critical way can thus open up new directions and insights in the relationship between water markets, water scarcity, and water security in Chile. Previous scholarship has considered the 
creation and operation of water markets, covering both private ownership and tradability, across regions and sectors, including among peasant and indigenous communities (Bauer, 1997, 1998b; Budds, 2004, 2009b, 2010; Hadjigeorgalis, 2008; Prieto, 2015, 2016; Romano and Leporati, 2002). Within this body of work, the relationship between the Water Code and water scarcity has been explicitly addressed by Budds $(2008,2009 a)$ in relation to the social dynamics of uneven water allocation in central Chile, by Guiloff (2013) in regard to the human rights dimensions of rural drinking water shortages in the same region, and by Prieto $(2015,2016)$ in the context of indigenous communities in northern Chile. The first objective of this paper is to go beyond these existing assessments of how the Water Code relates to scarcity - in theory by addressing it, but in practice by producing it - to how far and in what ways the policy framework is mobilised, and is effective, in addressing acute water scarcity.

The second objective is to extend previous analyses of how water-society relations have become configured in Chile under the Water Code, to consider how they affect interventions towards water security in the face of growing scarcity, and their wider dynamics, agendas, and implications. Budds (2013) related the actors and discourses involved in the development of the Water Code with the dual motives of capital accumulation and elite political power from the 1970s, arguing that these relations were evident in the debate over the 2005 modification of the legislation, in which three related groups (conservative politicians, neoliberal analysts, industrial sectors) that substantially benefited from the framework lobbied for minimal reforms. While this showed how the Water Code reshaped water-society relations, the 
relational approach to water security outlined above offers the opportunity to consider two further aspects. First, how water is produced under the Water Code: how it is supplied, regulated, defined, and perceived, and how those characteristics shape users' responses to water scarcity. Second, what is being secured through water security interventions in response to water scarcity, and for whom.

Linking the production of water and the recasting of hydrosocial relations with responses to scarcity will help to elucidate the specific mechanisms through which water insecurity is created, as well as shed light on the nature, agendas and prospects of particular water security initiatives. I will proceed to explore these questions through the experiences of, and responses to, the 2014-15 drought in the La Ligua river basin, following a brief account of the evolution and contestation of the Water Code.

\section{$\underline{3 .}$ The evolution and contestation of Chile's Water Code}

The 1981 Water Code formed part of the free-market economic reforms that characterised all areas of public policy during Chile's military dictatorship (1973-90), in the absence of political opposition (Bauer, 1998a). The Water Code enabled existing water rights to be converted into private property, which were decoupled from land to facilitate a market in water trading. Water 
rights could be transferred - inherited, gifted, leased, traded ${ }^{5}$ - when properly filed at property registries, and were protected under the military government's 1980 Constitution. ${ }^{6}$ Private water rights could only be expropriated by the state at full market value (Budds, 2013), which has precluded this measure on a large scale. ${ }^{7}$

Water rights applied to all uses, such as agriculture, industry and mining. Water rights were needed for urban drinking water networks, but not for rural drinking water supply, as this was considered an automatically legitimate use. Separate water rights were needed for surface water and groundwater resources, despite these often being interconnected (Budds, 2004, 2009a). Water rights were obtained in three ways: (i) existing water rights could be converted into private water rights (through regularisation); (ii) water rights to available sources were obligatorily allocated by the state to applicants (free of charge); and (iii) water rights could be purchased from other owners. Once available water rights for a particular source were fully allocated, redistribution was expected to happen through the market according to supply and demand, and no prioritisation between uses was thus set. As such, the role of the

\footnotetext{
${ }^{5}$ Trading refers to the sale of the permanent water right, while leasing refers to the sale of volumes of water (corresponding to all or part of the entitlement) deriving from the permanent right.

${ }^{6}$ See Bauer (1998a) for a full description of the Water Code and its history, and Budds (2013) for an analysis of its politics.

${ }^{7}$ The state has repurchased water rights in very few cases, some of which were undertaken to redress historic dispossession of water among indigenous groups (Budds, 2009b).
} 
National Water Directorate (Dirección General de Aguas, DGA) was to administer the system, and regulation was delegated to water user organisations, mainly irrigation canal user associations, and basin-wide Vigilance Committees (Junta de Vigilancia). ${ }^{8}$ As private property, water rights were governed by civil (private) law, and conflicts were to be resolved between users or the civil courts rather than by the DGA.

In sum, therefore, the Chilean framework is based on three key private and market principles. First, the use of the market to manage demand, whereby users are incentivised to buy or sell water rights according to the value of the intended use. Second, the designation of water rights as private property protected by the state, which provides users with a security of tenure that was expected to encourage user investment in water infrastructure. Third, the delegation of regulation to water user organisations, deemed to avoid potentially politicised and bureaucratic government decision-making.

These provisions transformed water-society relations in Chile in both material and symbolic ways. First, despite water being defined as a "national good for public use" (bien nacional de uso público) in the Water Code and the Constitution, ${ }^{9}$ the conversion of water rights to private property enclosed and privatised water to rights-holders, and curtailed the state's role in governing Chile's water (and its watersheds, aquatic environments, and water-related

\footnotetext{
${ }^{8}$ As groundwater was not widely used in 1981 , groundwater user committees were introduced under the 2005 reform of the Water Code.

${ }^{9}$ The meaning of this crucial phrase is ambiguous, and is at the heart of ongoing moral and legal debate in Chile as to whether water is, and/or should be, "public" or "private".
} 
ecosystem services). Second, the transferability of private water rights changed water's identity from a public resource to a private commodity, which incentivised strategies of accumulation (Budds, 2004). Third, the Water Code defined individual ownership of water rights (person, organisation, or company), thereby precluding collective tenure, which was reinstated for groups self-identifying as indigenous under the 1993 Indigenous Law. Fourth, it converted water rights from the relative measure of a share of a water flow (in an irrigation canal or from a communal well), measured as a fraction of the flow, to the absolute volume of water from a source, a fixed amount measured metrically in litres per second. This measure was intended to facilitate water rights trading by making clear exactly how much water a right represented (Bauer, 1998a). ${ }^{10}$ Fifth, moving to private regulation by water users could potentially enable those parties to dominate water management beyond the wider public interest, and privilege water users with better access to the means (financial resources, knowledge, social status) to enforce regulation (Budds, 2004).

The outcomes of the Water Code were much debated during the controversial process of amending it over 13 years between 1992 and 2005 (Budds, 2013). The key concern was the potential to encourage the accumulation of water rights for speculative purposes. Although data were not collected, most

\footnotetext{
${ }^{10}$ This change was complicated on two counts: converting existing shares of flows to litres per second for the purposes of regularisation, and for practical water sharing when flows are reduced, as there is no obligation for earlier users to reduce their extraction in order to ensure that subsequent entitlements are fulfilled; unless a drought is officially declared, which enables the DGA to order all users to reduce their extractions proportionally.
} 
observers agreed that markets were inactive throughout Chile (Bauer, 1997; Budds, 2004; Prieto, 2015), even if interpretations differed over whether it mattered (Muchnik et al., 1997). Unequal access to groundwater rights among small farmers was also noted, as the low level of historic groundwater use meant that many wells needed new water rights (Budds, 2004, 2008). Environmental concerns were raised, including the lack of provision of minimum flows for rivers (which post-dated 1981), or the ability to assess aquifer capacity before allocating groundwater rights. Nevertheless, Budds (2013) argues that this debate was less about overcoming the limitations of the Water Code, and more about maintaining the privatised and marketised system that was an emblematic legacy of the military regime. The process resulted in modest changes to the Water Code in 2005, the most significant being a system of fees for non-use of water rights (increasing with length of time and northward location) to deter speculation.

Following these contested and modest amendments, it was difficult to envisage future major reforms to the Water Code (Larraín and Segura, 2017). However, attention became refocused on the Water Code and its effects from 2008, when water crises in several regions of Chile highlighted the overabstraction of water, as well as illegal extraction of groundwater (i.e. without the corresponding water rights), which were attributed to the lack of external regulation of water users. Two cases became particularly emblematic. The La Ligua river basin in the centre north became the focus of water theft. Some national politicians (government ministers, congressional deputies) with farms investing in export agriculture were accused of drawing groundwater either beyond the entitlement of their water rights, or without water rights, with 
some cases prosecuted by the DGA. Widespread illegal extraction affected the livelihoods of small farmers, who relied on irrigation canals and small wells that had become diminished or dry (Budds, 2004). The Copiapó basin in northern Chile became the example of over-allocation of water rights. This grape-producing region had become increasingly dominated by mining, whose representatives had lobbied the DGA to allocate additional water rights to meet its needs.

These cases provoked renewed and reinvigorated public critiques of the Water Code. They attracted attention from civil society organisations, which had previously campaigned about water-related injustices (especially around hydroelectric dams), but not the policy framework itself. Possibly inspired by the major and enduring university student demonstrations in 2011 , old and new, and national and local, civil society organisations started campaigning for 'private' water to be made 'public', as illustrated by Figure 1.

[FIGURE 1 HERE]

Figure 1: Poster advertising a preparatory event for the National Water March, Santiago, 2013, organised by a coalition of civil society organisations. The captions read "Preparatory day for the carnival march for the defence and recuperation of water" (top) and "let's take back our water!" (bottom) (source: Latin American Observatory of Environmental Conflicts [Observatorio Latinoamericano de Conflictos Ambientales], Chile, http://olca.cl/articulo/nota.php?id=102950, accessed 1 September 2017). 
Soon after taking office, the second government under Michelle Bachelet (2014-18) responded by setting up a National Water Resources Task Force in March 2014. It was headed by a presidential delegate, who was tasked with assessing the functioning of the market-led water policy framework throughout Chile, assisted by regional delegates, and compiling a report that would form the basis of a new legislative reform bill, which was submitted to Congress in 2015.

What emerged from 2012, therefore, is a situation in which the effectiveness and the legitimacy of the Water Code were being increasingly and publicly questioned. What is of interest for this paper is how this related to Chile's most pressing water issue: drought. How far and in what ways were the principles of the Water Code mobilised to address regional water crises? How were responses to drought configured, and what were their motivations and implications? To explore these questions, I now turn to the nature of, and responses to, acute water scarcity in the La Ligua river basin during the 201415 drought.

\section{Securing water for accumulation: Responses to drought in the La Ligua} $\underline{\text { river basin }}$ 
La Ligua is a small river basin with a semi-arid climate, located in Petorca Province $^{11}$ in Chile's Valparaíso Region (Fifth Administrative Region). La Ligua River rises in the Andean foothills (Figure 2), meaning that it benefits from snowmelt in spring but not in summer, when demand for irrigation is highest. The main economic activity is agriculture, with farms ranging from large commercial properties (approximately 100-500 hectares) to smallholdings owned by beneficiaries of agrarian reform or subsequent buyers (approximately 2-12 hectares) (ODEPA-CIREN, 2014, 2017).

[FIGURE 2 HERE]

Figure 2: Location of the La Ligua river basin, Chile (source: Budds, 2004, adapted from IGM, 1984)

Until the 1990s, agriculture comprised a mix of commercial fruit production from larger farms, and annual crops from smaller farms, mainly irrigated by canals drawing surface water from La Ligua River. Thereafter, fruit production for export - mainly avocados - increased due to a combination of several factors: an optimal climate, a growing export market, accessibility of drip irrigation systems, access to untilled land on the valley sides, and, importantly, the availability of groundwater rights from the hitherto

\footnotetext{
${ }^{11}$ Petorca Province comprises Petorca, Cabildo, La Ligua, Papudo, and Zapallar Municipalities. La Ligua river basin covers Cabildo, the southern half of La Ligua, and Papudo.
} 
underexploited aquifer (Budds, 2004). Table 1 shows estimated avocado production in the La Ligua river basin between 2002 and 2017, indicating a steep increase between 2002 and 2008 as plantations expanded, followed by a similarly sharp decline from 2014 , as a result of drought.

\section{[TABLE 1 HERE]}

Table 1: Estimate of area of land under avocado production in the La Ligua river basin, 2002-2017 (ODEPA-CIREN, 2002, 2008, 2014, 2017). ${ }^{12}$

With the increase in fruit plantations, applications for available groundwater rights rose steeply. By 1996, the amount requested was so large that the DGA suspended the approval of applications while it commissioned a hydrogeological study to determine allocation. ${ }^{13}$ Meanwhile, many farmers continued to drill wells, and extract groundwater illegally, taking advantage of

\footnotetext{
12 This is a rough estimate because data are produced by political-administrative unit rather than watershed. The figures for La Ligua river basin comprise all production in Cabildo and Papudo Municipalities, and half of that for La Ligua Municipality. This is likely to slightly underestimate the total, given the greater productivity of land in La Ligua (southern half of La Ligua Municipality) than Petorca river basin (northern half).

13 Demand for groundwater rose from an estimated 5267 litres per second in 1995, to 10,134 litres per second in 2004, with a further estimated illegal groundwater extraction of 13,859 litres per second by the same year (Budds, 2009a).
} 
the lack of external monitoring and enforcement (Budds, 2009a). ${ }^{14} \operatorname{In} 2004$, the DGA finalised groundwater allocation, and closed the aquifer to further applications. $^{15}$ As around 90 per cent of avocado plantations were irrigated with efficient micro spray or drip irrigation systems (ODEPA-CIREN, 2017), this enabled the expansion of land for fruit production.

Until 2009, the basin had been able to sustain the expanded agricultural production in years with normal precipitation, with acute scarcity emerging only in dry years (related to El Niño). ${ }^{16}$ This was likely due to the water reserves in the aquifer, which supported much of the new agricultural land. However, from the onset of a prolonged drought in 2010 onwards, most summers became characterised by severe water scarcity, caused by a combination of successive dry winters, increased groundwater extraction, and exacerbated by higher water demand from matured fruit plantations. ${ }^{17}$

These trends are documented by Chilean government agencies (e.g. DGA, National Meteorological Directorate). By 2015, water scarcity was evident throughout Chile, as manifested in river flows and reservoir levels of between

\footnotetext{
14 The DGA had an administrative, but not regulatory, role. Following the legislative reforms in 2005, the DGA was able to monitor illegal groundwater extraction when denounced by affected users, although this was hampered by a lack of resources and frequent refusals of access by landowners.

${ }^{15} 25$ per cent of the total allocated groundwater flow was allocated as provisional rights, which were annulled in March 2014 due to impacts on the aquifer.

${ }^{16}$ All seasons refer to those of the southern hemisphere.

${ }^{17}$ Personal communication, local government official 1, La Ligua, June 2015.
} 
50 and 80 per cent below normal (DGA, 2015). In March 2016, the Valparaíso Region had the greatest hydrological deficit in the country, with surface water (rivers and reservoirs) between 30 and 100 per cent below normal levels (DGA, 2016). By 2015, a state of agricultural emergency was in place in 194 municipalities throughout Chile - including in Petorca Province from 2008 until at least 2017 - and a National Drought Management Plan (2015) was announced (Gobierno de Chile, 2015). While these reports focus on meteorological conditions and field observations, the contribution of high water demand for Chile's natural resource based economic activities is also acknowledged (Comisión de Recursos Hídricos y Desertifiación, 2016).

By 2010 , the effects of severe water scarcity were visible on the valley's landscape. In 2009, La Ligua River ceased flowing, and has since only returned during flash floods. By 2013, flows in irrigation canals had successively reduced, and large areas of fruit trees had been cropped due to the lack of water. ${ }^{18}$ Water table levels had fallen significantly, from levels of approximately $5-20 \mathrm{~m}$ in the $1990 \mathrm{~s}$ and 2000 s (Budds, 2004), to $80-120 \mathrm{~m}$ from around $2013,{ }^{19}$ leaving many shallower wells dry, including most of those belonging to small farmers.

\footnotetext{
${ }^{18}$ Cropping avocado trees is a strategy of last resort to keep them alive with the least water possible. Trunks are typically painted white to deflect the sun and prevent scorching (see Figure 5). If irrigation is resumed, the tree will take 2-3 years to grow back.

${ }^{19}$ Multiple accounts in the field, La Ligua, May-June 2015.
} 
[FIGURE 3 HERE]

Figure 3: Landscape in the upper La Ligua valley with new avocado plantations in autumn 2003 (source: author).

\section{[FIGURE 4 HERE]}

Figure 4: Landscape from Figure 3 photographed from a slightly different angle in winter 2015 (source: author).

[NB. FIGURES 3 AND 4 COULD FORM A COMPOSITE IMAGE]

These conditions became acute in the drought of the 2014-15 summer. Irrigation canals were dry throughout most of the middle and lower sections of the basin, and flowed at about 25 per cent of capacity in the upper section. ${ }^{20}$ Only the deepest wells of approximately 80 metres plus yielded water. ${ }^{21}$ Many fruit plantations had been cropped, reflected in the area dedicated to avocado production (Table 1), as well as testimonies of local government officials. ${ }^{22}$ Some farms used their available water to concentrate irrigation to a smaller area, while others became unproductive, leading to temporary abandonment and switch to paid labour, or bankruptcy and repossession, or

\footnotetext{
${ }^{20}$ Personal communications, small farmers' leaders 1, 2 and 3, upper La Ligua valley, June 2015.

${ }^{21}$ Personal communications, commercial farmers 1 and 2, La Ligua, June 2015.

${ }^{22}$ Personal communication, local government official 1, La Ligua, June 2015.
} 
conversion to other uses, including annual crops or low density livestock. ${ }^{23}$ This is substantiated by data on the size of fruit plantations in Petorca Province, which show that both the number of farms and the total area decreased between 2014 and 2017, with the largest decline - approximately 15 per cent - in the smallest landholdings of under five hectares, suggesting that land either ceased fruit production, or that smaller plantations became consolidated into larger properties (ODEPA-CIREN, 2014, 2017). The entire landscape became dry, dusty, barren, and lifeless - in short, desertified (Figure 5).

[FIGURE 5 HERE]

Figure 5: A part abandoned and part cropped fruit plantation in La Ligua, June 2015. The land had been repossessed by the lending bank, which paid a caretaker to maintain an area of lemon trees using water volumes purchased from another landowner (source: author).

Immediate responses to the drought comprised largely individual solutions. These included deepening existing wells, funds permitting, ${ }^{24}$ which is allowed

\footnotetext{
${ }^{23}$ Personal communications, small farmers' leaders 4 and 5, central and lower La Ligua valley, June 2015 .

${ }^{24}$ Approximately USD 300 per metre depth, La Ligua, 2015.
} 
under the Water Code as it defines water yield but not depth of extraction. ${ }^{25}$ Another common response comprised drilling a new well in a different place on the same landholding to find water, and applying to transfer the groundwater rights from the dry well; ${ }^{26}$ a legal fix that helps to ensure that groundwater rights can be fulfilled in the context of depletion. ${ }^{27}$ Many farmers also constructed surface storage ponds to be filled by groundwater, again funds permitting (Figure 6). Landowners who had abandoned their plantations, but whose wells still yielded water, sold volumes of water to other farmers (as in Figure 5). It is important to note that this trading represents a temporary transaction of water that is derived from a permanent groundwater right, and that the groundwater right itself is not sold, meaning that this does not entail a permanent reallocation of water from one user to another.

Interviews with stakeholders in La Ligua suggested that sales of permanent water rights had not increased in response to drought, mainly because water was not present to fulfil many surface water or groundwater rights due to the drought. Any sales were thought most likely to have occurred together with sales of land upon the disposal of farms, as in the past (see Budds, 2004). ${ }^{28}$

\footnotetext{
${ }^{25}$ Personal communication, commercial farmer 3, central La Ligua valley, June 2015.
}

${ }^{26}$ Groundwater rights are registered with the geo-coordinates of the point (well) from which they are drawn, and their relocation requires authorisation.

${ }^{27}$ Personal communication, regional government official, Quillota, June 2015.

${ }^{28}$ Formal records are challenging to review, because sales of water rights are recorded in hand-written registers at Property Rights Registries, which take time to update. 
[FIGURE 6 HERE]

Figure 6: A new surface storage pond in the upper section of La Ligua, June 2015 (source: author).

The irrigation canals that had previously been the mainstay of agriculture on the traditional valley floor ran either low or dry, and most became effectively obsolete. While canal associations claimed that they continued to hold meetings and collect dues ${ }^{29}$ some irrigation canals, especially in the badly affected lower section of the basin, were no longer being maintained (Figure 7).

[FIGURE 7 HERE]

Figure 7: Unmaintained irrigation canal, lower La Ligua valley, June 2015 (source: author).

Furthermore, the drought did not only affect agriculture, but also rural drinking water supply systems organised by village-based autonomous committees or cooperatives. Most systems relied on wells, which are exempt from formal

\footnotetext{
${ }^{29}$ Personal communications, small farmers' leaders 1,2 and 3, upper La Ligua valley, June 2015.
} 
water rights as they are for rural drinking water, and most of which ran dry. This water had to be replaced by emergency water tankers, which are private licensed operators contracted by the La Ligua municipal government (under its obligation to provide potable water), ${ }^{30}$ and which supplied around one third of the rural population of the valley from 2011 to $2016 .^{31}$ The operators were entrepreneurs who owned land and water rights in La Ligua basin, and drew water from deep wells in the valley for the tankers (Figure 8). ${ }^{32}$ In other words, the state was obliged to buy water that it used to control from private owners in order to fulfil its citizens' basic needs.

[FIGURE 8 HERE]

Figure 8: Private tanker drawing water in La Ligua valley, June 2015 (source: author).

In response to increasing water scarcity in La Ligua, various government agencies announced emergency measures from 2010, mainly funded by the Central Government, and all of which were coordinated by the Petorca Provincial Government.

\footnotetext{
${ }^{30}$ Personal communication, local government official 2, La Ligua, June 2015.

${ }^{31}$ Personal communication, local government official 3, La Ligua, June 2015.

${ }^{32}$ Personal communication, local government official 4, La Ligua, June 2015.
} 
In November 2010, the Ministry of Public Works declared a six-month "Drought Zone" (Zona de Escasez Hídrica) for Petorca Province, which was subsequently extended nine times until September 2016 (with gaps from June-October 2013 and October 2015 - March 2016). ${ }^{33}$ This measure allowed the DGA to reduce or suspend water rights, although designated no additional financial resources to undertake these activities.

The DGA had already started to control illegal groundwater extraction, in response to the aforementioned water theft in 2011. It mandated the formation of a Vigilance Committee in La Ligua, as one never existed, although the water users have not enacted it. It also mandated seven Groundwater Committees, to be responsible for installing meters on legal wells, although these have also not become active. It started to legalise historic groundwater rights for the rural drinking water systems; while not technically needed to extract water, they enable legal action against other users who are infringing their rights.

In February 2012, the Ministry of the Interior declared a 12-month "Disaster Zone" (Zona de Catástrofe) due to drought for Petorca, La Ligua and Cabildo Municipalities, ${ }^{34}$ which was extended for two years. ${ }^{35}$ This measure carried

\footnotetext{
${ }^{33}$ Ministry of Public Works Decree 403, 24 November 2010; Decree 223, 6 June 2011; Decree 416, 7 December 2011; Decree 225, 12 June 2012; Decree 362, 13 December 2012; Decree 289, 11 October 2013; Decree 235, 10 April 2014; Decree 422, 13 October 2014; Decree 129, 14 April 2015; Decree 154, 24 March 2016.

${ }^{34}$ Supreme Decree 234, 28 February 2012.
} 
the greatest institutional weight. It prioritised drinking water, and funded the water tankers. It also facilitated the construction of emergency irrigation infrastructure, which including deepening wells, lining irrigation canals with concrete, and building water storage ponds.

A subsequent six-month measure passed in October $2014^{36}$ enabled the Directorate of Hydraulic Works to undertake measures comprising the improvement of rural drinking water sources, new wells for irrigation and drinking water, improvements to irrigation canals and storage ponds, and river restoration. It also provided resources for feasibility studies for artificial aquifer recharge and a desalination plant for rural drinking water (see below). In August 2014, agricultural taxes for small and medium-sized farmers were also waived. ${ }^{37}$

Alongside these emergency relief measures, two longer-term measures were also defined. First, a major irrigation reservoir for La Ligua, which had been pending for several decades, and had been widely partly blamed for water shortages in La Ligua (see Budds, 2004, 2008). Second, a coastal desalination plant, which would supply rural drinking water systems, thereby replacing the dry wells and tankers, which were costing La Ligua Municipality

\footnotetext{
${ }^{35}$ Supreme Decree 133, 1 February 2013; Supreme Decree 1422, 29 July 2014. The Disaster Zone was later extended to Papudo Municipality (Supreme Decree 1776, 24 November 2014).

${ }^{36}$ Supreme Decree 1776, 28 October 2014.

${ }^{37}$ Supreme Decree 1523, 23 August 2014.
} 
approximately USD 400,000 per month. ${ }^{38}$ The desalination plant would produce additional irrigation water, and would require a large financial contribution from farmers (MOP, 2017b).

In January 2008, the Ministry of Agriculture declared the first "Agricultural Emergency" (Emergencia Agrícola) for Petorca Province, lasting for two years and targeted at small farmers and the rural population. It included measures to support agriculture, such as improving irrigation canals, and promoting drip irrigation. The National Institute for Agricultural Development (Instituto Nacional de Desarrollo Agropecuario, INDAP) - the government agency that supports those classified as peasant farmers - however, promoted collective solutions among this farming sector, including shared surface water storage ponds and communal irrigation wells, which it considered more efficient and cost-effective than individual solutions. This provision also waived agricultural taxes, and for peasant farmers also cancelled credit repayments and disbursed grants of USD 430-715. Further Agricultural Emergencies were declared in February 2011, April 2014, and March 2015.

In parallel, the team of the regional presidential delegate for water in the Valparaíso Region was working to raise awareness of water issues and stimulate organisation among water users, through activities including threemonthly 'round table' meetings. INDAP also sought to foster organisation among its users, in order to implement the collective solutions that it was pursuing.

\footnotetext{
${ }^{38}$ Personal communication, local government official 5, La Ligua, June 2015.
} 
Responses in La Ligua can thus be categorised as follows: individual measures, short-term drought relief, longer-term infrastructure solutions, and state-led user organisation. These responses converge on the goal of increasing water supply to sustain the level of agriculture that has developed since the 1990s, either directly, through technology and infrastructure to rationalise existing and develop additional sources, or indirectly, by bolstering mechanisms to support these interventions, such as tax waivers and user organisation. What is also remarkable, however, is that these measures are neither supported by a comprehensive hydrological study that would inform responses, nor a process of land use planning that would assess the limits of agricultural expansion. While state agencies and water users broadly agreed that increasing the supply of water in both the short and long terms was an appropriate response to drought, less attention and scrutiny were directed towards the potential for these new sources of water to fuel fresh demand and thus further expansion, rather than secure existing needs.

In the next section, I analyse the dynamics, motives and implications of these responses, in order to assess what exactly they served to secure.

\section{Managing Drought: The internal contradictions of the Water Code}

By comprising predominantly supply-led and state-led actions, responses to drought in La Ligua addressed the symptoms of water scarcity as opposed to its causes. The increase in water provision served to sustain a paradigm of agricultural development that was inequitable and unsustainable, and avoided challenging the power relations that underpin it. As one local government 
official observed, ${ }^{39}$ the crisis presented a choice between further perpetuating the current mode of agricultural development and supply-led water solutions that privileges commercial farmers, or taking the opportunity to restructure agriculture to promote a viable mix of small and large farmers producing for domestic, niche and export markets within the limits of the valley's resources. The responses described above fit squarely with the former.

Moreover, what is also evident from these responses is the absence of the core principles of the Water Code: the use of the market in water rights to manage demand, the security of private property to promote user investment in infrastructure, and the delegation of regulation to users and their organisations. I will now take each of these aspects in turn to assess how they relate to responses to the drought.

Despite low supply and high demand under drought, an active water market in water rights had not emerged. Most users were using their available water, many irrigation canals and wells did not yield any/enough water to fulfil rights, and illegal groundwater use persisted despite some DGA enforcement. ${ }^{40}$ Water trading appeared to be limited to some sales of temporary water volumes, deriving from permanent water rights, which does not entail

\footnotetext{
${ }^{39}$ Personal communication, local government official 1, La Ligua, June 2015.

${ }^{40}$ Due to its widespread nature, easiness to undertake, reliance on informants, and limited resources. Personal communication, local government official 6, La Ligua, June 2015.
} 
reallocation in response to demand on a permanent basis, as envisaged under the Water Code (see Romano and Leporati, 2002). ${ }^{41}$

Furthermore, the possibility under the Water Code for the government to either repurchase or expropriate water rights was not considered. No interviewee mentioned the possibility of these measures, and when prompted, described them as irrelevant or unworkable. Besides the moral question of whether the state should pay private parties to reclaim resources that it had previously relinquished at no cost, expropriation is considered a very extreme and sensitive measure in Chile, as it was employed for agrarian reform and renationalisation under the governments of Eduardo Frei (1964-70) and, especially, Salvador Allende (1970-73), and remains politically untenable for its perceived violation of private liberty. ${ }^{42}$

Responses to drought privileged infrastructure, which were to be largely state directed and financed, with minimal input from water users. While new major infrastructure, including the reservoir and desalination plant, could likely not be developed without government support and finance, smaller works implemented under the emergency programmes, such as improvements to irrigation canals, were simply imposed, thereby precluding any wider

\footnotetext{
${ }^{41}$ It is also possible that any land being repossessed or sold would include the water rights that were being used on it (see Budds, 2004).

${ }^{42}$ In past and current proposals to amend the Water Code, the term 'expropriation' has provoked strong political resistance (Budds, 2013).
} 
discussion of the problematic or exploration of solutions with farmers. ${ }^{43}$ In addition, while the water users interviewed agreed that state-led infrastructure projects and improvements were necessary, there was little consideration of how these would be organised and financed, or how end users would be involved in decision-making. As a large hydraulic project that would benefit farmers, the irrigation reservoir would require a 70 per cent financial contribution from users, although my interviews suggested that farmers had little sense of how the water would be owned, priced, and distributed. ${ }^{44}$ While the proposed desalination plant would require a 90 per cent contribution presumably to subsidise its construction so as to render it economically viable for the supply of rural drinking water (MOP, 2017b) - interviews with water users indicated that they had given little consideration to the eventual level of water tariffs and their affordability for rural consumers, or the governance implications of the replacement of customary wells with desalinated water. ${ }^{45}$

The prevalent response to water scarcity thus comprised state-led and topdown infrastructure solutions, with a sense that these were simultaneously

\footnotetext{
${ }^{43}$ Personal communications, small farmers' leaders 4 and 5 , central and lower La Ligua valley, June 2015 .

${ }^{44}$ Personal communications, local government official 1, La Ligua, June 2015; commercial farmer 4, central La Ligua valley, May 2015; and small farmers' leaders 4 and 5, central and lower La Ligua valley, June 2015.

${ }^{45}$ Rural water supply systems receive government funding for infrastructure, and thereafter water charges fund operation and maintenance. MOP (2017b) states that the production cost of desalinated water will be USD 0.34 per cubic metre, excluding land purchase for infrastructure and returns for the operator.
} 
implemented by the state and expected by water users. There was little parallel social mobilisation or organisation of water users around either the causes of scarcity, or potential solutions. Indeed, the principal efforts towards local social organisation that I observed in 2015 were led by two state actors: the regional presidential delegate's team in holding round table meetings, and INDAP's pursuit of collective solutions. In 2010, a new local civil society organisation, Modatima ${ }^{46}$ formed around a campaign to publicise water theft and its effects on local people. ${ }^{47}$ Yet, agricultural community leaders stated that protesting about water scarcity and its causes would be futile. ${ }^{48}$ One explanation for this stance is that traditional farming organisations have become less active with both the shift from surface water to groundwater use and growing water scarcity, which have rendered canals less significant as irrigation sources. Since small farming has declined, irrigation canal associations have become less important and active, and neither the Vigilance Committee nor the Groundwater Committees were as yet operational.

\footnotetext{
${ }^{46}$ Movement for the Defence of Access to Water, Land and Environmental Protection (Movimiento de Defensa por el Acceso al Agua, la Tierra y la Protección del Medio Ambiente) emerged in Petorca Province in 2010, comprising professionals and local people who highlight and challenge illegal water extraction, and advocate the abolition of private water rights.

${ }^{47}$ Personal communication, civil society representative, La Ligua, June 2015.

${ }^{48}$ Personal communications, small farmers' leaders 1, 2 and 3, upper La Ligua valley, June 2015.
} 
This suggests that what is at stake is not simply how water is managed under the Water Code, but rather how the framework has transformed the relationship between water and society in Chile. In section 3, I identified five key changes: privatisation, commodification, individualisation, metrication (shares to litres per second), and private regulation. My contention is that these changes have shaped stakeholders' interactions with, and attitudes towards, water in ways that have constrained responses to drought. I thus suggest that these hydrosocial relations, fostered by the Water Code, now present a set of internal contradictions that are serving to undermine it.

In particular, this transformed relationship between water and society has been counterproductive to responses to drought, having fostered supply-led solutions, the state's reliance on private water sources for emergency drinking water provision, and individualised behaviour among water users. I associate individualised behaviour with three specific factors. First, the conversion of water rights into private property, which has both encouraged strategies of accumulation, and has disregarded the wider public interest. Second, the definition of water rights as individual entitlements, and the metrication from water shares to litres per second, which have fostered competitive rather than cooperative behaviour in some instances as users strive to extract their entitlements amid reduced flows. Third, the dynamics of groundwater and wells, which by their nature foster individual rather than collective management and governance.

It is these transformed hydrosocial relations, I contend, that are producing internal contradictions to challenge the water policy framework in new and 
more profound ways. Until now, the negative effects associated with the Water Code - hoarding and speculation, lack of access to groundwater, and illegal extractions - had not seriously affected the principal groups who supported and benefited from it. However, the production of scarcity under the framework, as well as its inability to manage that scarcity - by not effectively managing demand, curbing illegal use, or controlling sources of water supply - is now undermining the interests of those groups, including commercial farmers who cannot draw their water and sustain their livelihoods. These contradictions are not easily addressed by proposals for better enforcement or minor reforms to the law, as in the past, or by the sorts of technical fixes that had been deployed up until then, such as surface storage ponds and transferring the geo-coordinates of dry wells.

The solutions mobilised, therefore, address the situation by increasing water supply and introducing supporting measures such as tax waivers. These serve to sustain existing important forms of accumulation and to stabilise these into the future, but without undertaking structural reforms to address the water insecurity to which they respond. This, in turn, requires protecting the Water Code, and the benefits of permanent, untaxed, unrestricted and deregulated flows of water that it represents for the stakeholders driving, and benefiting from, capital accumulation: large-scale commercial water users, conservative politicians (who support and/or have interests in these industries), and technical experts (who are ideologically aligned and/or have links with industries and politicians) (Budds, 2013). Thus, supplying water does not just alleviate the effects of drought, but sustains export agriculture 
and, moreover, obscures the limitations of the Water Code so as to reduce pressure for its reform.

\section{$\underline{\text { 6. Conclusion }}$}

This paper has explored the relationship between Chile's privatised and marketised water policy framework and water security amid growing water scarcity. In the context of one of the worst - but by no means the only affected areas, La Ligua, my analysis shows that the framework has neither led to the effective management of demand, nor security of water rights, under conditions of scarcity. Instead, it has played a counterproductive role in responses to drought, by privileging supply-led solutions driven by the state, and individualised measures that impede collective action or user protagonism. This supports previous findings from Chile that lack of water availability does not necessarily stimulate efficiency and trading, but rather the development of new sources of water (Budds, 2004, 2009b). Yet, rather than conclude that market-oriented provisions should be refined or better mobilised in order to improve water security amid scarcity, I suggest that it is precisely those aspects - the privatised, individualised and deregulated approach to water management, rather than the tradability of water per se - that both exacerbate scarcity as well as constrain responses to it.

Moreover, I argue that these outcomes do not merely derive from the nature of the law and its implementation, but rather stem from the ways in which the Water Code has reconfigured hydrosocial relations in Chile. It is these relations, characterised by privatisation and individualisation, that have impeded 
effective drought responses, the effects of which now serve to potentially undermine the framework, thus presenting an internal contradiction. In this way, responses to drought are oriented towards supplying water to maintain existing forms of capital accumulation, and, in turn, the privatised and marketised water framework that enables it amid mounting challenges from its failure to address water shortages, thus satisfying the dual demands of Chile's economic and political elites. In other words, supply-led drought responses do more than secure water; they sustain the power relations that enable the status quo to survive.

The findings underscore the importance of approaching water security not in terms of material water, but rather as water-society relations that have evolved in particular ways. While the water security literature treats water as homogenous and universal, and as the object of interventions, my analysis suggests that policy changes give rise to distinct forms of material and symbolic interaction between people and water in specific contexts, which in turn influence outcomes - in this case, responses to drought. Moreover, shifting the focus from water itself to the nature of hydrosocial relations directs attention to the underlying dynamics and motives of water security interventions, shedding light on their wider implications, and calling into question the validity of generalised assertions and proposals for specific contexts.

\section{$\underline{\text { References }}$}

Bakker, K., 2000. Privatizing water, producing scarcity: the Yorkshire drought 
of 1995. Economic Geography 76 (1), 4-25.

Bakker, K., 2002. From state to market?: Water mercantilización in Spain.

Environment and Planning A 34 (5), 767-790.

Bakker, K., 2003. An Uncooperative Commodity: Privatizing Water in England and Wales. Oxford University Press, Oxford.

Bakker, K., 2010. Privatizing Water: Governance Failure and the World's Urban Water Crisis. Cornell University Press, Ithaca.

Bauer, C., 1997. Bringing Water markets down to earth: the political economy of water rights in Chile, 1976-95. World Development 25 (5), 639-656.

Bauer, C., 1998a. Against the Current? Privatization, Water Markets and the State in Chile. Kluwer, Boston.

Bauer, C., 1998b. Slippery property rights: multiple water uses and the neoliberal model in Chile 1981-1995. Natural Resources Journal 38 (1), 109155.

Bauer, C., 2015. Water conflicts and entrenched governance problems in Chile's market model. Water Alternatives 8 (2), 147-172.

Birkenholtz, T., 2013. On the network, off the map': developing intervillage and intragender differentiation in rural water supply. Environment and Planning D: Society and Space 31, 354-371.

Budds, J., 2004. Power, nature and neoliberalism: the political ecology of water in Chile. Singapore Journal of Tropical Geography 25 (3). 322-342. Budds, J., 2008. Whose scarcity? The hydrosocial cycle and the changing 
waterscape of La Ligua river basin, Chile. In: Goodman, M., Boykoff, M., Evered, K. (Eds.) Contentious Geographies: Environment, Meaning, Scale, Ashgate, Aldershot, pp 59-68.

Budds, J., 2009a. Contested $\mathrm{H}_{2} \mathrm{O}$ : science, policy and politics in water resources management in Chile. Geoforum 40, 418-430.

Budds, J., 2009b. The 1981 Water Code: the impacts of private tradable water rights on peasant and indigenous communities in Northern Chile. In:

Alexander, W., (Ed.) Lost in the Long Transition: The Struggle for Social Justice in Neoliberal Chile. Lexington Books, Lanham, pp. 35-55.

Budds, J., 2010. Water rights, mining and indigenous groups in Chile's Atacama. In: Boelens, R., Guevara, A., Getches, D. (Eds.) Out of the Mainstream: Water Rights, Politics and Identity. Earthscan, London, pp. 197211.

Budds, J., 2013. Water, power, and the production of neoliberalism in Chile, 1973-2005. Environment and Planning D 31, 301-318.

Budds, J., Linton, J., McDonnell, R., 2014. The hydrosocial cycle. Geoforum 57, 167-169.

Budds, J., Loftus, A., 2014. Water and hydropolitics. In: Desai, V., Potter, R. (Eds.) The Companion to Development Studies. Routledge, London.

Budds, J., McGranahan, G., 2003. Are the debates on water privatization missing the point? Experiences from Africa, Asia and Latin America. Environment and Urbanization 15 (2), 87-113. 
Comisión de Recursos Hídricos y Desertifiación, 2016. Informe de la Comisión de Recursos Hídricos y Desertifiación recaido en el proyecto de ley que faculta al estado para la creación de plantas desalinizadoras [Report of the Commission on Water Resources and Desertification on the legislative bill that enables the state to establish desalination plants], Bulletin 9862-33-1, 23 May 2016. Comisión de Recursos Hídricos y Desertifiación. Congress of the Republic of Chile, Valparaíso.

Dirección General de Aguas (DGA), 2016. Información pluviométrica, fluviométrica, estado de embalses y aguas subterráneas [Rainfall, streamflow, reservoir and aquifer information]. Bulletin no. 455, March. Government of Chile, Santiago.

Dirección General de Aguas (DGA), 2015. Información pluviométrica, fluviométrica, estado de embalses y aguas subterráneas [Rainfall, streamflow, reservoir and aquifer information]. Bulletin no. 443, March. Government of Chile, Santiago.

Dirección General de Obras Públicas (DGOP), 2017. Estudio de seguridad hídrica en Chile en un contexto de cambio climático para elaboracion del Plan de Adaptación de los recursos hídricos al cambio climático [Study of water security in Chile in the context of climate change to formulate a climate change adaption plan for water resources]. Government of Chile, Santiago.

Donoso, G., Blanco, E., Foster, W., Franco, G., Lira, J., 2012. Seguridad hídrica y alimentaria en América Latina y España: El caso de Chile [Water and food security in Latin America and Spain: The case of Chile]. Internal report. Pontificia Universidad Católica de Chile, Santiago. 
Grey, D., Sadoff, C., 2007. Sink or swim? Water security for growth and development. Water Policy 9, 545-571.

Gobierno de Chile, 2015. Plan Nacional para la Sequía [National Drought Management Plan]. Government of Chile, Santiago. Retrieved from:

https://www.gob.cl/noticias/las-medidas-que-componen-el-plan-nacional-para$\underline{\text { la-sequia/ }}$

Guiloff, M., 2013. El derecho al agua como un derecho humano: El caso de la Provincia de Petorca [The right to water as a human right: The case of Petorca Province]. In: Vial, T. (Ed.) Informe Anual Sobre Derechos Humanos en Chile 2013 [Annual Report on Human Rights in Chile 2013]. Ediciones Universidad Diego Portales, Santiago.

Hadjigeorgalis, E., 2008. Distributional impacts of water markets on small farmers: is there a safety net? Water Resources Research 44 (10), W10416. Instituto Geográfico Militar (IGM), 1984. Mapa Hidrográfico de Chile [Map of Hydrological Basins of Chile]. Government of Chile, Santiago.

Jepson, W., Budds, J., Eichelberger, L., Harris, L., Norman, E., O’Reilly, K., Pearson, A., Shah, S., Shinn, J., Staddon, C., Stoler, J., Wutich, A., Young, S., 2017. Advancing human capabilities for water security: a relational approach. Water Security 1 (1), 46-52.

Kaika, M., 2003. Constructing Scarcity and Sensationalizing Water Politics: 170 Days that Shook Athens. Antipode 35 (5), 919-954. 
Larraín, S., Segura, P., 2017. Las reformas amenazadas [Reforms under threat]. In: Anonymous, Recuperar el Agua [Reclaiming Water]. Monde Diplomatique, Santiago.

Linton, J., 2010. What is Water? The History of a Modern Abstraction. UBC Press, Vancouver.

Linton, J., Budds, J., 2014. The hydrosocial cycle: Defining and mobilizing a relational-dialectical approach to water. Geoforum 57, 170-180.

Loftus, A., 2006. Reification and the dictatorship of the water meter. Antipode 38 (5), 1023-1045.

Loftus, A., 2015. Water (in) security: Securing the right to water. The Geographical Journal 181 (4), 350-356.

Loftus, A., Budds, J., 2016. Neoliberalizing water. In: Springer, S., Birch, K., MacLeavy, J. (Eds.) The Handbook of Neoliberalism. Routledge, London.

Ministerio de Obras Públicas (MOP), 2017a. Minuta de posición Región de Valparaíso "Plan Chile 30/30 obras públicas y agua para el desarrollo" [Position paper of the Valparaíso Region for "Chile National Plan 30/30 for public works and water for development]. Government of Chile, Santiago. Retrieved from:

http://www.mop.cl/participacion_ciudadana/Documents/consulta_2017/Minuta \%20de\%20Posicion\%20Region\%20de\%20Valparaiso.pdf

Ministerio de Obras Públicas (MOP), 2017b. Plantas desalinizadoras Provincia de Petorca, Región de Valparaíso, Provincias de Limarí y Choapa, 
Región de Coquimbo [Desalination Plants - Petorca Province, Valparaíso

Region; Limarí and Choapa Provinces, Coquimbo Region]. Government of

Chile, Santiago. Retrieved from:

https://www.camara.cl/pdf.aspx?prmID=49493\&prmTIPO=DOCUMENTOCO

MISION.

Muchnik, E., Luraschi, M., Maldini, F., 1997. Comercialización de los

Derechos de Aguas en Chile [Commodification of Water Rights in Chile].

Economic Commission for Latin America and the Caribbean, Santiago.

Oficina de Estudios y Políticas Agrárias (ODEPA) y Centro de Información de Recursos Naturales (CIREN), 2002. Catastro Frutícola - V Region [Fruit

Production Survey - Valparaíso Region]. Government of Chile Santiago.

Oficina de Estudios y Políticas Agrárias (ODEPA) y Centro de Información de Recursos Naturales (CIREN), 2008. Principales Resultados, Catastro

Frutícola: Región de Valparaíso [Principal Results, Fruit Production Survey:

Valparaíso Region]. Government of Chile, Santiago.

Oficina de Estudios y Políticas Agrárias (ODEPA) y Centro de Información de Recursos Naturales (CIREN), 2014. Catastro Frutícola, Principales

Resultados: Región de Valparaíso [Fruit Production Survey, Principal Results: Valparaíso Region]. Government of Chile, Santiago.

Oficina de Estudios y Políticas Agrárias (ODEPA) y Centro de Información de Recursos Naturales (CIREN), 2017. Catastro Frutícola, Principales

Resultados: Región de Valparaíso [Fruit Production Survey, Principal Results: Valparaíso Region]. Government of Chile, Santiago. 
O’Reilly, K., 2006. “Traditional” women, "modern” water: Linking gender and commodification in Rajasthan, India. Geoforum 37 (6), 958-72.

Pahl-Wostl, C., Palmer, M., Richards, K., 2013. Enhancing water security for the benefits of humans and nature - the role of governance. Current Opinion in Environmental Sustainability 5, 636-684.

Peña, H., 2016. Desafíos de la seguridad hídrica en América Latina y el Caribe [Water security challenges in Latin America and the Caribbean]. Natural Resources and Infrastructure paper series 178. United Nations Economic Commission for Latin America and the Caribbean, Santiago. Perreault, T., 2006. From the Guerra Del Agua to the Guerra Del Gas:

Resource Governance, Neoliberalism and Popular Protest in Bolivia. Antipode $38(1), 150-72$.

Prieto, M., 2015. Privatizing water in the Chilean Andes: the case of Las Vegas de Chui-Chiu. Mountain Research and Development 35 (3), 220-229.

Prieto, M., 2016. Bringing water markets down to Chile's Atacama Desert. Water International 41 (2), 191-212.

Romano, D., Leporati, M., 2002. The distributive impact of the water market in Chile: a case study in Limarí Province, 1981-1997. Quarterly Journal of International Agriculture 41, 41-58.

Schulpen, L., Gibbon, P., 2002. Private sector development: policies, practices and problems. World Development 30 (1), 1-15

Spronk, S., 2007. The politics of water privatization in the Third World. Review of Radical Political Economics 39 (1), 126-131. 
Swyngedouw, E., 1995. The contradictions of urban water provision - A study of Guayaquil, Ecuador. Third World Planning Review 17 (4), 387-405.

Swyngedouw, E., 1999. Modernity and hybridity: nature, regeneracionismo, and the production of the Spanish waterscape, 1890-1930. Annals of the Association of American Geographers 89 (3), 443-465.

Swyngedouw, E., 2005. Dispossessing $\mathrm{H}_{2} \mathrm{O}$ : The contested terrain of water privatization. Capitalism Nature Socialism 16 (1), 81-98.

Vandewalle, E., Jepson, W., 2015. Mediating water governance: Point-of-use water filtration devices for low-income communities on the US-Mexico border. GEO: Geography and Environment 2 (2), 107-121.

World Economic Forum, 2011. Water Security: The Water-food-energyclimate Nexus. Island Press, Washington. 